Please refer to the definitive version of this article when citing:

Cohen, S.A., Hanna, P. \& Gössling, S. (2017). The dark side of business travel: A media comments analysis. Transportation Research Part D: Transport and Environment, DOI: 10.1016/j.trd.2017.01.004

\title{
The Dark Side of Business Travel: A Media Comments Analysis
}

\begin{abstract}
The publication of 'A darker side of hypermobility' (Cohen \& Gössling, 2015), which reviewed the personal and social consequences of frequent travel, led to considerable media coverage and sparking of the public imagination, particularly with regards to the impacts of business travel. It featured in more than 85 news outlets across 17 countries, engendering over 150,000 social media shares and 433 media comments from readers, with the latter a source of insight into how the public reacts online when faced with an overview of the negative sides of frequent business travel. The present paper is theoretically framed by the role of discourse in social change and utilises discursive analysis as a method to evaluate this body of media comments. Our analysis finds two key identities are performed through public responses to the explicit health and social warnings concerned with frequent business travel: the 'flourishing hypermobile' and the 'floundering hypermobile'. The former either deny the health implications of frequent business travel, or present strategies to actively overcome them, while the latter seek solace in the public dissemination of the health warnings: they highlight their passivity in the construction of their identity as hypermobile and its associated health implications. The findings reveal a segment of business travellers who wish to reduce travel, but perceive this as beyond their locus of control. Business travel reductions are thus unlikely to happen through the agency of individual travellers, but rather by changes in the structural factors that influence human resource and corporate travel management policies.
\end{abstract}

Keywords: hypermobility; business travel; health; wellbeing; media; discourse analysis

\section{Introduction}

Travelling fast, far and frequently is increasingly common in contemporary societies. Such hypermobility is typically tied to affluence, which affords the power to move, and materialises in corporeal movements such as frequent business travel and leisure trips, lifestyle migration or visits to spatially dispersed friends and relatives. In contrast to approaches that have focused on the environmental impacts of hypermobility (e.g. Shaw \& Thomas, 2006), a parallel but fragmented body of literature exists, dispersed across multiple disciplines, that ties frequent travel to negative health and wellbeing implications. A recent paper by Cohen and Gössling (2015), entitled 'A darker side of hypermobility' draws upon a range of inter-disciplinary secondary material to synthesise the extant literature on the negative consequences of frequent business and leisure travel into three sides: physiological; psychological \& emotional; and social. It argued that these 'costs' tend to be overshadowed in society by the popular representation in discourse of travel as glamorous. Travel is glamorised by a range of social 
mechanisms, such as visualisations on social media that encourage mobility competition, frequent flyer programme status levels and the mass media and travel industry who depict tourism and business travel as desirable (ibid).

'A darker side of hypermobility' received significant media coverage, with journalists honing in on its discussion of the negative consequences of business travel. Within three months of the publication of the paper in August 2015, it had received coverage in 85 news outlets across 17 countries, engendering over 150,000 shares on social media. It can consequently be argued that the paper engendered a sparking of the public imagination. The direct media coverage generated 433 comments from readers (August-October 2015), which are in themselves a potential source of rich insight into how the public reacts online when faced with an overview of the negative sides of frequent business travel. The media comments presented an opportunity to explore the ways in which people negotiate and respond to explicit physical, psychological, and social health warnings surrounding hypermobility. The present paper employs discourse analysis to evaluate and discuss this corpus of media comments. In doing so, it contributes to the broader research problem of whether and how health and wellbeing concerns may offer a more effective evidence base to stimulate reductions in travel than environmental arguments, and indeed, whether the dual agendas can act in synergy. Shaw and Thomas (2006) viewed the reluctance among the hypermobile to travel less as a classic example of the 'tragedy of the commons', i.e. their 'sacrifice' would be perceived as useless if not followed by others. It is therefore important to understand if and how the more direct or 'internal' health and wellbeing consequences of frequent travel, as opposed to just the 'external' environmental costs, might provide greater leverage in stimulating behavioural transitions.

The paper next turns to a review of the negative personal costs of frequent business travel and the role of discourse in social change, before introducing the methodology, which includes discussion of user-generated content as data and the paper's method of discourse analysis. The focus then turns to presentation and discussion of the empirical findings, centring on the discursive strategies and identity work that were revealed, and which locates individuals through two key subject positions: the 'flourishing hypermobile' and the 'floundering hypermobile'. The paper concludes by considering the implications of the discourses that were uncovered, not only in terms of the potential for issues of wellbeing to provide leverage for reducing hypermobility among some frequent business travellers, but also the structural level at which interventions for change are likely to be most fruitful.

\section{The dark side of business travel}

It is necessary at a contextual level to summarise the evidence base on the costs of frequent business travel that Cohen and Gössling (2015) provided, which requires disentangling their discussion of business travel from that of leisure travel, as the online comments that form the data for this paper were a direct response to media reporting on the business travel aspects of their study. Before doing so, it is crucial to recognise that the popular discourse on business travel overwhelmingly constructs it as a prestigious and glamorous activity (Thurlow \& Jaworski 2006), and that there is substantial academic discourse that draws attention to positive aspects of business travel. For instance, benefits to business travellers are alleged to include enhanced professional status, a broadened understanding of cultural differences, the development of cosmopolitan identities and increased open-mindedness (Beaverstock, Derudder, Faulconbridge \& Witlox 2009; Gustafson 2014). Thurlow and Jaworski (2006: 124) argue however that the discourse of cosmopolitanism through travel 'is one of many liberal 
discourses which run through the mythology of globalization', in which airline and lifestyle advertising 'talk' or 'write' the notion of the global citizen into existence, as a model or 'mythic identity' that 'persuade us to spend and consume'.

Although academic studies have given emphasis to both the benefits and negative effects of frequent business travel (e.g. Gustafson 2014; Tretyakevich 2015), the latter are in contrast far less prominent in public discourse, despite the significant academic discourse that does exist on the 'darker sides' of business travel (e.g. Bergström 2010; Black \& Jamieson 2007). Frequent business travellers have been shown to incur social psychological costs at kinship, friendship and community levels (Cohen \& Gössling 2015). Isolation and loneliness is a frequently reported experience, both for the traveller and those left behind at home (Gustafson, 2014). The geographically dispersed connections that business travellers often make through work tend to come at the expense of ties at local and community scales (Gustafson, 2014). Even with advances in communication technologies, there is an association between frequent business travel and less time for co-present social life at home (Bergström, 2010). The traveller's family role may be reduced by repeated absence from key family events, such as birthdays, and the quality of time spent at home may be degraded by the limited time there being spent on recovering from fatigue before the next trip (Black \& Jamieson, 2007).

Business travel is a traditionally male sphere (Bergström Casinowsky, 2013), and as such it is heavily gendered (Aguiléra, 2008; Gustafson 2006). Households with a male frequent business traveller often also include a 'stay at home' wife who is prevented from engaging in some dimensions of the labour market due to domestic constraints (Black \& Jamieson, 2007). In cases where women are both frequent travellers and mothers, they are under pressure from others, and themselves, to fulfil the role of mother while away (Black \& Jamieson, 2007; Bergström Casinowsky, 2013).

Beyond these social and psychological consequences that Cohen and Gössling (2015) reviewed, their paper identified a range of physiological costs from frequent business travel that are rarely discussed. With business travel characterised by short trips, by car or train, but often by airplane, it is in cases where frequent air travel is involved that the array of threats to travellers' health is most profound. As Beaverstock et al. (2009) observe, the majority of business travel, and its associated impacts, is facilitated at a global level by flying. While jet lag is the most commonly cited physiological impact of frequent business travel, little discussed is that the condition can persist up to six days after flying (Waterhouse, Reilly \& Edwards, 2004), and its interference with the body's circadian rhythm can disrupt a range of biological processes (Archer et al. 2014). Accumulation of fatigue from jet lag, amalgamated with travel stress, may turn chronic, and has been termed 'frequent traveller exhaustion' (Black \& Jamieson, 2007; Ivancevich, Konopaske \& DeFrank, 2003; Striker, Dimberg \& Liese, 2000).

The risk of developing deep-vein thrombosis during flight has received significant media coverage, whereas less attention has been given to the radiation exposure that frequent business travellers receive: there have been calls for frequent business travellers, along with airline crew, to be classified as 'radiation workers' (Barish \& Dilchert, 2010). Further physiological impacts on frequent business travellers include the stress of work continuing to accumulate while away (Beaverstock et al., 2009) and other transport-related stressors such as technical failures, additional security checks and weather delays (Ivancevich et al., 2013). Finally, business travel can be relentless, with sensitive data in the hands of fatigued individuals who may put their companies at risk, and who may be operating in unfamiliar cultural environments whilst meeting rigid schedules (Welch, Welch \& Worm, 2007). This is all in the context of long 
working days, late evenings, and early mornings, with less time for exercise, usually worse eating habits than when at home, and often, the overconsumption of alcohol (Beaverstock et al., 2009; Gustafson, 2014). It is in reaction to media reporting on these manifold personal and social impacts of frequent business travel that this paper's discourse analysis of media comments must be understood. Firstly however, this paper turns to its theoretical framing in terms of how we can understand the construction of discourse and the possibilities it opens up for societal change.

\section{Discourse and the challenge of change}

Academic work employing a notion of discourse often turns to the work of Michel Foucault (e.g. Rose, 1989; 1998). Foucault's early work (e.g. 1989; 2002) largely drew on two key concepts to understand discourse - power and knowledge. Unlike many of his contemporaries, Foucault argued that power should not be conceptualised in a deterministic sense whereby it is something that is 'owned' by some and exerted or imposed on others in a repressive manner (e.g. Foucault, 2002). Power does not flow in a unilateral sense but is circular; it is not the 'property' of any individual or group, rather it is constitutive, as it creates subjects (Heyes, 2007). In order to flow in unilateral ways power is inherently interlinked with understandings of 'knowledge'. Knowledge is not something 'out there' in the 'real' world waiting to be discovered by advancing scientific inquiry, but rather is produced through a set of principles, procedures and 'discourses' which enable its 'discovery' (Foucault, 1991). Knowledge is established, presented, and maintained through a particular organisation of discourse with counter-discourses being suppressed, repressed or abolished at the same time, through for example, taken-for-granted assumptions (Foucault, 2002). Through dominant 'knowledges' individuals are therefore positioned as particular types of 'subjects' (1989; 2002). This positioning constrains the array of behaviours, experiences and feelings with which each individual can engage. Practices are formed in relation to the individual and legitimate 'ways of being' are constructed. It is through dominant discourses that particular knowledges gain status and essentially power, facilitating the legitimisation of certain practices and behaviours (Foucault, 1990a).

Whilst Foucault's conceptualisation of power and knowledge offers a resource to examine social phenomena in a more complex manner (Goldstein, 2003), his understanding of the 'subject' within this framework is problematic on a number of levels (McCarthy, 1990). Throughout his works, Foucault alludes to notions of resistance within this broader power/knowledge nexus yet he is criticised for leaving these largely un-theorised and there "...remains no category around which a notion of active agency may be formulated" (McNay, 1994, p7). Thus, Foucault's understanding of power and knowledge has also led to the suggestion that he is a 'prophet of entrapment' due to his disregard for individual agency (Simons, 1995), with his understanding of power and knowledge being described as 'hyperdeterminism' (Dean, 1994), leaving little hope for change (Taylor, 1984).

To overcome these critiques, we turn to Foucault's work on ethics to understand how social change can be possible through a discursive framework. In his later work on 'ethics' and technologies of the self (e.g. 1990b; 1992; 1997), Foucault maintains the location of the self both within a nexus of power/knowledge, whilst also allowing for an agentic subject that, through counter-discourses, can resist dominant 'ways of being' (Smith, 2001). Foucault suggested that 'technologies of the self' represent a series of techniques that individuals adopt and exercise in order to work on themselves and conduct themselves in conjunction with a 'way of living' (Foucault, 1990b; 1992). However, there are not infinite ways to resist; people 
are not completely trapped through discourse, nor can they be completely 'free' (Yates \& Hiles, 2010; Heyes, 2007). It is through this that the individual is able to reflect on, and resist, the complex dynamics of power/knowledge through counter-discourses and critical reflection. Such theorising has been adopted in a range of social and political disciplines. For example, in feminist studies this theoretical understanding has been utilised to enable women to contest, challenge or resist 'fixed' patriarchal identities in their everyday lives through counterdiscourses (e.g. Coole, 1993; Heyes, 2006, 2007; Markula, 2003). Further it has helped scholars to expose and challenge contemporary discourses surrounding climate change (e.g. Kurz, Augoustinos \& Crabb, 2010; Hanna, Scarles, Cohen, \& Adams, 2016). It is through this work, concerned with notions of resistance and social change that we theoretically position this paper, and attention now turns to how we mobilise this through our methodology.

\section{Methodology}

\subsection{Our data}

Over the past fifteen years internet use has been rapidly increasing throughout the world. For example, the latest figures suggest that in November 2015 just under half $(46.4 \%)$ of the world was using the internet, a figure representing 3.3 billion people. These internet users represent a growth of $832.5 \%$ since the turn of the millennium (Miniwatts-Marketing-Group, 2016). Such is the importance of the internet in the daily lives of many that academics have become increasingly interested in the internet. In psychology for example, using the internet, and the ways in which internet use offers alternative understandings of the 'self' and 'identity', have driven the development of a new sub-discipline, that of 'Cyberpsychology' (e.g. Riva \& Galimberti, 2001). In addition, a prominent development in the patterns of internet use has been the rise in social media (Correa, Hinsley, \& De Zuniga, 2010) and user-generated content (Van Dijck, 2009). Arguably both social media use and user-generated content now play an important role in many individuals' lives, offering them the space to construct opinions, identities and notions of the self (Kaplan \& Haenlein, 2010). Such potential has not gone unnoticed from researchers looking to utilise online material to explore questions central to modern life.

For example, Potthast, Stein, Loose, and Becker (2012) highlight the ways in which 'comments boards' on internet websites represent rich forms of social data. They argue that these comments sections provide online spaces in which individuals can directly and instantaneously express opinions and criticism of current issues as they play out. Furthermore, Abdul-Mageed (2008, p. 75) suggests that comments sections provide a rich source of social data as they not only allow individuals to express opinions but that such public expressions of opinions enable researchers to expose the ideologies that are reflected in them. Finally, research in the Netherlands (Schuth, Marx, \& de Rijke, 2007) that sought to explore public understandings of immigration utilised the user-generated comments section on internet news articles. The rationale for their project was born on the theoretical assumption that such contemporary 'spaces' offer 'ordinary people' the opportunity to express opinions, construct arguments and express notions of their 'selves' they might not otherwise be able to (Schuth et al., 2007). With a compelling argument for the use of user-generated comments in social research, this research will consequently draw on a range of online news article comments to address how people negotiate and respond to explicit physical, psychological, and social health warnings surrounding hypermobility. 
To do so we draw on comments made in relation to the direct reporting of a recent academic article published in Environment and Planning A (Cohen \& Gössling, 2015). This work corralled a range of inter-disciplinary secondary literature to argue that frequent travel entails a number of physiological, psychological \& emotional and social consequences that tend to be overshadowed in society by the popular representation of travel as glamorous. The media focused on the business travel aspect from this study, resulting in a range of coverage in outlets such as The Telegraph (Anderson, 2015) and The Economist (AW, 2015), culminating in a 10 minute TV segment on the research on the show CNN Business Traveller (CNN, 2015). The article in The Economist, titled 'The sad, sick life of the business traveller' was shared more than 100,000 times alone on social media, including more than 15,000 comments on Facebook.

For the purpose of this research we tracked every news outlet directly reporting on the original journal article for three months immediately following its publication. We then compiled a database documenting all news outlets which resulted in data from 85 media articles across 17 countries. From these publications there were a total of twenty media articles (shared 91,020 times) that had direct 'comments' discussion contributions resulting in a total of 433 comments (21,187 words) for our analysis (see Table 1$)$. A limitation of the comments as a source of data is that they are not representative of the wider population: they only reflect individuals who had been willing to publicly post a comment, leaving the voices of those who may have read but not posted, or not read the media article(s) at all, unheard. The comments also have come almost exclusively from present or former frequent business travellers, omitting the views of the family members of frequent business travellers. Furthermore, the demographics of those leaving comments are not publicly available, with the consequence that any skew, for instance, in gender or country of origin, are not objectively identifiable.

\begin{tabular}{|l|l|l|}
\hline Media outlet & $\begin{array}{l}\text { Number } \\
\text { of } \\
\text { comments }\end{array}$ & Link \\
\hline Daily Mail & 25 & $\begin{array}{l}\text { http://www.dailymail.co.uk/travel/travel_news/article- } \\
\text { 3206314/The-dark-frequent-flying-Academics-warn- } \\
\text { consequences-include-physiological-emotional-damage.html }\end{array}$ \\
\hline Der Standard & 16 & $\begin{array}{l}\text { http://derstandard.at/2000020297329/Forscher-beklagen- } \\
\text { einseitige-Glorifizierung-des-Jetsettens }\end{array}$ \\
\hline $\begin{array}{l}\text { Fast } \\
\text { Company }\end{array}$ & 8 & $\begin{array}{l}\text { http://www.fastcompany.com/3050543/hit-the-ground- } \\
\text { running/why-frequent-business-travel-is-so-bad-for-you }\end{array}$ \\
\hline FAZ & 3 & $\begin{array}{l}\text { http://www.faz.net/aktuell/beruf-chance/ungesunder-lebenstil- } \\
\text { von-reisen-risiken-und-nebenwirkungen-13767650.html }\end{array}$ \\
\hline $\begin{array}{l}\text { Financial } \\
\text { Times }\end{array}$ & 70 & $\begin{array}{l}\text { http://www.ft.com/cms/s/0/f8ac893a-5096-11e5-b029- } \\
\text { b9d50a74fd14.html\#axzz3ngRyY2ya }\end{array}$ \\
\hline $\begin{array}{l}\text { Frugal } \\
\text { Travel Guy }\end{array}$ & 16 & $\begin{array}{l}\text { http://www.frugaltravelguy.com/2015/09/does-frequent-travel- } \\
\text { make-us-sick-lonely-and-mentally-unstable-new-report-says- } \\
\text { yes.html }\end{array}$ \\
\hline $\begin{array}{l}\text { Huffington } \\
\text { Post }\end{array}$ & 25 & $\begin{array}{l}\text { http://www.huffingtonpost.com/entry/dark-side-of- } \\
\text { travel_55c22c13e4b0138b0bf49320 }\end{array}$ \\
\hline $\begin{array}{l}\text { Lawyers } \\
\text { Weekly }\end{array}$ & 3 & $\begin{array}{l}\text { http://www.lawyersweekly.com.au/news/17006-lawyers- } \\
\text { warned-on-the-dark-side-of-frequent-flying }\end{array}$ \\
\hline Mashable & 2 & $\begin{array}{l}\text { http://mashable.com/2015/08/04/downside-of- } \\
\text { traveling/\#9Bax0QSbiOkM }\end{array}$ \\
\hline
\end{tabular}




\begin{tabular}{|c|c|c|}
\hline ND TV & 1 & $\begin{array}{l}\text { http://www.ndtv.com/offbeat/frequent-flyers-lose-health-family- } \\
\text { love-too-1204216 }\end{array}$ \\
\hline $\begin{array}{l}\text { News } \\
\text { Medical }\end{array}$ & 1 & $\begin{array}{l}\text { http://www.news-medical.net/news/20150804/New-study- } \\
\text { shows-frequent-travel-promotes-stress-loneliness-and-long- } \\
\text { term-health-problems.aspx }\end{array}$ \\
\hline news.com.au & 4 & $\begin{array}{l}\text { http://www.news.com.au/travel/travel-advice/the-dark-side-of- } \\
\text { cabin-crew-life-sadness-sickness-and-loneliness/story- } \\
\text { fn6yjmoc-1227540569764 }\end{array}$ \\
\hline $\begin{array}{l}\text { One Mile At } \\
\text { A Time }\end{array}$ & 23 & $\begin{array}{l}\text { http://onemileatatime.boardingarea.com/2015/08/05/frequent- } \\
\text { travel-glamorous/ }\end{array}$ \\
\hline Science 2.0 & 1 & $\begin{array}{l}\text { http://www.science20.com/news_articles/frequent_travel_dama } \\
\text { ging_to_health_and_wellbeing_study-156771 }\end{array}$ \\
\hline $\begin{array}{l}\text { Smart } \\
\text { Company }\end{array}$ & 1 & $\begin{array}{l}\text { http://www.smartcompany.com.au/people/48210-fast-lane-the- } \\
\text { darker-side-of-business-travel.html }\end{array}$ \\
\hline $\begin{array}{l}\text { smarter } \\
\text { Travel }\end{array}$ & 2 & $\begin{array}{l}\text { http://www.smartertravel.com/blogs/up-front-with-tim- } \\
\text { winship/will-frequent-travel-be-the-death-of- } \\
\text { you.html?id=24852839 }\end{array}$ \\
\hline $\begin{array}{l}\text { The } \\
\text { Advertiser }\end{array}$ & 3 & $\begin{array}{l}\text { http://www.adelaidenow.com.au/travel/travel-advice/the-dark- } \\
\text { side-of-cabin-crew-life-sadness-sickness-and-loneliness/story- } \\
\text { fni0bfoj- } \\
1227540569764 \text { ? sv=33efc1608581690d3da323b09299bed0 }\end{array}$ \\
\hline $\begin{array}{l}\text { The } \\
\text { Economist }\end{array}$ & 83 & $\begin{array}{l}\text { http://www.economist.com/blogs/gulliver/2015/08/frequent- } \\
\text { flyers }\end{array}$ \\
\hline $\begin{array}{l}\text { The } \\
\text { Telegraph }\end{array}$ & 107 & $\begin{array}{l}\text { http://www.telegraph.co.uk/finance/newsbysector/transport/118 } \\
\text { 11449/How-business-travel-can-make-you-seriously-sick.html }\end{array}$ \\
\hline Zeit Online & 39 & $\begin{array}{l}\text { http://www.zeit.de/karriere/2015-08/geschaeftsreisen- } \\
\text { gesundheit-studie }\end{array}$ \\
\hline
\end{tabular}

\section{Table 1: Sources of media comments}

\subsection{Method of analysis}

Discourse analysis is a qualitative method of analysis that is said to offer a 'tool' to de-construct language and examine the ways in which language produces meaning (Clarke \& Saraga, 2003). Adopting a discursive approach enables the researcher to examine the ways language is used to create particular versions of reality in specific situations to offer interpretations as to why discourse is delivered and perhaps more crucially, what it achieves (Bhavnani \& Phoenix, 1994). Within the broad umbrella of discourse analysis it is argued that there are a variety of discourse analysis techniques (Gill, 2000; Wetherell, 1998). Such techniques include three broad approaches which can be labelled: Foucauldian discourse analysis (e.g. Parker, 1992; Parker, 1994), critical discourse analysis (e.g. Fairclough, 2013), and discursive psychology (e.g. Potter \& Wetherell, 1987). Whilst all three offer interesting approaches to discourse and data, the focus of this research is specifically on how discourse enables certain 'ways of seeing' and 'ways of being' (e.g. Foucauldian Discourse Analysis) in addition to exploring how individuals use discourse to manage favourable social identities (e.g. Discursive Psychology) (Edwards \& Potter, 1992).

Foucault argued that language and discourse is always productive, constituting human subjects (Oberhuber \& Krzyzanowski, 2008) in a discursive economy in which availability of discursive 
resources is often limited (Foucault, 1980). Thus, Foucauldian Discourse Analysis (FDA) (e.g. Parker, 1992) calls for consideration of the ways in which power and knowledge function through discourse to construct objects and achieve certain subject positions, subjectivities and ways of being. Such subject positions both enable and constrain individuals to experience and practice 'life' in a particular way due to the broader discursive structure of rights and obligations for those subject positions (Davies \& Harré, 1999). In this analysis FDA will be drawn on to examine subject positions, how discourses relate to others, links to broader power structures and how discourses can justify structures which legitimate particular practices, relationships and 'feelings' (Parker, 1994; 1999; 2004).

Alternatively, Discursive Psychology (DP) (Potter \& Wetherell, 1987) understands language as a social practice that has a performative function that individuals can actively use. From this position individuals are said to apply a range of discursive strategies in their talk, for example, 'footing', 'extreme case formulations' or 'softening the blow', which are used to achieve a particular function and construct a specific version of 'self' (Derek Edwards, 2000; Speer \& Potter, 2000). The use of discursive strategies allows the speaker to manage stake in the interaction, and to also potentially offer some resistance to the more normative understandings of particular topics (Willig, 2008). The examination of such discursive strategies will enable this research to explore how individuals construct accounts of their frequent business travel behaviours.

Therefore, in their crudest forms, FDA will be used to establish broad discourses on a macro or social level and DP will be drawn on to examine the intimate use of language on a micro or individual level. This synthesis of the two versions has been advocated as it provides a fuller discursive analysis drawing on aspects from both traditions (Madill \& Gough, 2008; Wetherell, 1998).

\section{Findings and discussion}

\section{Discursive strategies and identity work}

Contemporary discourses surrounding frequent flying construct and locate individuals through two key subject positions. We have characterised these as: the 'flourishing hypermobile', an individual who fully embraces frequent flying and offers it up as an integral part of their 'happiness' and ultimately 'identity'; and the 'floundering hypermobile', an individual who understands frequent flying as a source to their physical and psychological distress, and a source to their fragmented and problematic identity. It must be stressed however that such discussions about frequent flying were not situated in the everyday conversations of our participants, rather they occurred as direct responses to the media reporting of a research paper articulating the negative physical, psychological and social impacts of frequent business travel. This is important not only to offer context, but also to highlight how for some, this negative account of frequent business travel might be seen as an identity threat, and for others a more concerning reality check.

It is also important to note that although the findings are presented here as dichotomous positions, on a discursive level they are inherently linked and both function to maintain the other. Though we did not seek to measure how many commenters viewed frequent business travel as positive or negative, the split between the two subject positions was roughly equal in 
number, however roughly one fifth of those commenting viewed frequent business travel ambiguously, or as a mixture of both positives and negatives. Utilising the discursive approach highlighted above, the following analysis is split broadly into the two alternative subject positions, with three sections within each of these to explore the ways in which thoughts, feelings, strategies, and identities function through dominant discourses to facilitate and legitimate the two broader subject positions. Thus our attention will now turn to those 'flourishing hypermobile' so prominent throughout our data.

\subsection{The flourishing hypermobile}

\subsubsection{Travel, agency and self-stylisation}

Throughout the internet comments across the range of media sources, those that adopted the position of the flourishing hypermobile did so in particular by drawing on an understanding of agency and the agentic subject (Giddens, 1991). Such an understanding of the 'modern' person is synonymous with contemporary neo-liberal subjects (Thompson \& Hirschman, 1995) in which the individual draws on discourses that function to highlight the extent to which humans are free from pre-existing structures (e.g. religion) and are able to engage in a journey of the search for identity (Rose, 1998). Such a journey has previously been suggested to be realised through the consumption of particular objects and products that act as identity symbols (e.g. a particular car or clothing label) as an attempt to express one's 'inner identity' (Dittmar, 2008). What is perhaps more interesting here however, is that work and productivity have traditionally been positioned in opposition to this consumerist discourse in ways that have suggested work and productivity are restrictive over agentic identities (e.g. class - see Marx \& McLellan, 2000). However, as the following extract shows, the nature of business travel can indeed be constructed as a work-related identity but in a wholly agentic manner:

"when I'm not travelling I wish I were travelling. For me its always been about the journey, getting from A to B, just as much as the destination itself. But these days I think I travel a lot smarter than I used to, I pace myself... pick flights that promise the most sleep and reduce jetlag, I don't do extra segments just to 'maximise' the experience and have more champagne, I spend as little time as possible in airports and lounges. Bottom line: can't wait for the next trip (which happens to be this weekend, transatlantic...)"

Here the individual commenting on the media report of the negative effects of frequent business travel immediately switches the focus of the discussion from business travel (i.e. work) to practices ("travelling", "journey") more akin to a discourse of leisure, travel, discovery and adventure (Hanna, 2013). In doing so, frequent business travel is not presented as the physical, psychological and social burden the original article suggests, but rather one in which the individual can construct their self-stylised identity as a well-travelled 'explorer' reminiscent of the ways in which the early European colonial explorers were constructed in historical travel writing (Kabbani, 1986). Such is the romanticism surrounding the notion of travel and exploration that the individual is no longer positioned as the passive recipient of the negative impacts of frequent business travel (as per the media article), but rather as the active agent that exploits their working environment/situation to maximise their happiness and "experience", longing for the next work assignment when not undertaking one (e.g. "when I'm not travelling I wish I were travelling", "can't wait for the next trip"). Furthermore, rather than ignoring the 
negative impacts of frequent business travel, the individual actively refers to "jetlag", "airports" and "lounges", but through the persistent use of the first person "I" draws on the identity of an experienced traveller (e.g. "these days I think I travel a lot smarter than I used to") to demonstrate how control and agency have enabled strategies (pacing oneself, avoiding "extra segments", selecting particular flight times) to overcome such negative impacts. Overall, discourses surrounding travel, coupled with the contemporary construction of the neo-liberal agentic subject, facilitate the position of the 'flourishing hypermobile' irrespective of the evidence presented in the media article which suggests the direct opposite.

It is not just this one example in which notions of agency and control are mobilised to mitigate the challenge to the frequent business flier's identity. As the following two extracts highlight, exercise and diet, as a contemporary form of both body work and identity construction (Heyes, 2006), were also utilised in the data set as active strategies to challenge the construction of the negative impacts of frequent business travel. Exercise and diet also enabled a self-stylisation and identity construction of the 'flourishing hypermobile' in opposition to those inexperienced, already unhappy (escaping other issues), or unable to access this desirable lifestyle 'choice':

"I always bring my running shoes and use the hotels' gyms. When dining out I look for healthier options, fresher dishes. There are apps to stay in touch and tricks to 'cheat' jetlag. Thus the impacts can be drastically reduced. I think the problem of many business travellers is that they escape from their own problems going into those trips, away from their "real worlds""

"most of us that do fly frequently for a living are able to adapt to the changes, and get over jet lag, exercise on-board to avoid DVT, and have equally full lifestyles - it just doesn't suit everybody. The same is true for any type of work"

Finally, not only did agency and control function as resources through which individuals can present positive self-identity in relation to their business travel and mitigating practices, but such 'benefits' were argued to spill over in to the everyday lives of individual through the ways in which not only is the desire to travel and personal satisfaction realised though their employment practice, but this also enables benefits to friends and family through the utilisation of 'air miles'. The following extract demonstrates the ways in which this added dimension functions to help to sustain the position as the flourishing hypermobile through not only their active work strategies (e.g. "in-box is very much under control"), the romantic and affective notions of travel ("I love my job and I love the travel") but also the ways in which the identity of the frequent business traveller enables benefits (as opposed to negative impacts as per the media article) to the individuals social life through the ability to "fly for free and invite my friends too":

"I can get a lot of work done on the plane and so my in-box is very much under control. When I have a holiday, I benefit from all my air miles and can therefore fly for free and invite my friends too... I love my job and I love the travel"

\subsubsection{Living the 'high' life: celebrity lifestyles}


Having explored the ways in which 'agency' and 'control' function to offer up the position of the 'flourishing hypermobile' that self-stylises through notions of experience and benefit often associated with travel and discovery (Shepherd, 2003), this section highlights the ways in which the practice of flying has been engineered through marketing and public discourse to present the practice as both desirable and also strongly associated with desirable contemporary social identities (Thurlow \& Jaworski, 2006), that is, those of celebrities. It has been long established that the 'celebrity identity' is useful in marketing as it offers potentially 'functional' products an added dimension to become markers of identity and resources through which individuals can perform identity work and construct their sense of self (e.g. Lindenberg, Joly, \& Stapel, 2011; McCracken, 1989). Such is the power of the discursive construction of the 'celebrity lifestyle' as 'glamorous', 'attractive' and 'desirable', and its association to flying and airline brand images (Erguven, 2015; Wang, Close, \& Ngamsiriudom, 2016) that within the construction of the subject position of the 'flourishing hypermobile' it featured prominently:

"I have been doing business travel for 20 years and I still think it is far more glamorous than the day to day existence of your usual Minion. I do four Australia to Minneapolis USA return trips across the pacific dateline and a couple of trips to UK/Europe every year. Plus 1-2 to SE Asia and a few domestic flights in Australia. I'm a top-tier FF with Qantas (and One World) for 10 years on the trot and nearly always get great service. I'm also a Diamond stayer with Hilton Brands Hotels and top tier with Intercontinental Hotel Group. I fly business class and often upgrade myself using FF points to get into First Class. Which is always spectacularly glamorous on any A380 or 747 across the Pacific or to Europe. I still love the experience, even when things go wrong! Airport Lounges are nowadays just so great, new aircraft are comfortable and in Business Class and luxurious First. Hotels with Hilton or IHG look after me like Royalty, its just fantastic in every way... What a life! And best of all, its all a business expense."

Throughout this extract it is not only the image of 'flying' that functions to present a positive self-representation in light of the negative impacts of frequent business travel presented in the media article, but rather a particular type of flying. This particular type of flying practice is one in which the individual is not just the average 'mass' traveller engaging in economy class, but rather the account is littered with tropes of social status symbols associated with air travel such as "top-tier FF [frequent flyer]", "Diamond Stayer", "business class", and "first class". Whilst these categories of travel status may well be a presentation of the individual's experience, the affective context of "love" for the experience, how the experience is "fantastic in every way", coupled with the "spectacularly glamorous" experiences, and the ways in which this construction is presented in direct opposition to the "day to day existence of your usual minion", all function as an active challenge to the presentation of the negative impacts of frequent business travel and help to mobilise and maintain the position of the 'flourishing hypermobile'. Furthermore, in this account even the airport lounge is presented as a space for relaxation and pampering, and the times "when things go wrong" are presented through an almost 'heroic' discourse in which the individual experiences pleasure in overcoming adversity, as opposed to experiencing notions of helplessness, passivity and distress often associated with air transport (Cohen \& Gössling, 2015). Finally, it is not only the agency an individual flying frequently for work-related activities has explicitly expressed as their source to happiness and a celebrity lifestyle, but also a rhetoric of 'out smarting your boss/corporation' is employed to further enhance the position of the flourishing hypermobile as someone fully in control of their life and exploiting the lifestyle choices available to them. 
In the following extract a similar array of discourses are employed to offer up the position of the 'flourishing hypermobile'. However, in what follows the individual goes further in terms of presenting the discourse of 'travel' as beneficial for the educated individual and offers up the suggestion that such travel practices are in no way having a negative impact on her physical, psychological, or social health, but rather are actively benefiting those elements of her life:

"I travel every week for my job as a consultant, and over the past 3 years every location I've worked in has been between a 3-9 hour flight from my home airport. I absolutely thrive in the travel environment. As a 30-something female, my mental and physical health has never been better and I am grateful for all of the different places I have been able to visit. By travelling, I have learned so much and feel that I have a greater appreciation for different peoples' points of view. Instead of complaining about having to travel, embrace the opportunity you have been given to explore different places on your company's dime!"

\subsubsection{Net gains and the rational thinker}

In addition to the ways in which the discourses surrounding air travel and the agentic subject facilitate a position of the 'flourishing hypermobile' despite the comments being made in relation to media articles reporting on the negative impacts of frequent business travel, this section explores the ways in which the contemporary discourses surrounding the construction of the 'rational' calculated individual further support this subject position. For example as the following person comments:

"the study points towards the fact that many of the ill-effects are within the control of the traveller. If you make a point of going to the gym at your hotel, don't drink too much and are able to enjoy the adrenalin and the interesting bits about seeing the world at the company's expense, the net effect can be positive"

In this extract are also many of the tropes already explored in this analysis surrounding the agentic subject and the ways in which the experienced frequent flyer actively adopts strategies to counter the potential negative impacts to maintain the position of the flourishing hypermobile. However here there is a more nuanced approach to maintain this position that draws on a discourse of education and rational thinking in which the "ill-effects" are explicitly accepted (though marginally overcome through a discourse of control and agency) but rationally weighed up against the benefits travelling can offer the individual, for example experiences of "adrenalin" and the contemporary understanding of "seeing the world" as an objectively 'good' thing for an individual (e.g. Stone \& Petrick, 2013 on learning through travel), offering a way in which the position 'flourishing hypermobile' is sustained through the calculated, overall "net effect" which in this case is presented as a "positive" gain.

In another comment a similar construction of frequent business travel is presented:

"As an international educator, I am quite immersed in a travelling lifestyle...Furthermore, to make a claim about incessant jet lag is far-fetched. Experienced travellers, more often than not, have found routines in order to battle jet lag. Finally, traveling should not be put into negative connotations. It's a way of bridging language and cultural gaps. It helps destroy stereotypes and negative images of other places" 
Throughout this extract a discourse of the 'experienced' traveller is constructed through the immediate presentation of the identity as an "international educator". This is followed up by an implicit construction of the 'inexperienced' traveller that has yet to take agency and control over their situation in order to adopt the strategies to overcome the potential negative implications of frequent travel. However, such a position is only momentary as the explicit rejection of the "far-fetched" claims being made surrounding the negative impacts is soon placed centre stage. However, in terms of the rhetorical strength of this position, the connotations of being an "international educator" and "experienced" traveller enable this critique of the evidence presented to be legitimated. Once again the calculating rational thinker is employed to suggest that in no way should the proposition of restricting or curtailing the practice of frequent flying be adopted as the net gain of frequent travel is a net positive benefit. Indeed, the benefits are not located simply within the individual but in relation to society as a whole. Again, this position resonates with tourism literature (Var, Brayley, \& Korsay, 1989) and is largely based on Gordon Allport's (1954) 'Contact Hypothesis' in which personal contact with an 'other' was suggested to be a key factor in prejudice reduction. Whilst this theoretical basis for prejudice reduction has long been dismissed as too simplistic and potentially prejudice provoking (e.g. Pettigrew, 1998) in this account it is utilised to maintain the position of the 'flourishing hypermobile' and actively dispute challenges to such lifestyles.

Whilst the two examples offered so far in this section highlight the more subtle ways in which discourses similar to those already presented in this analysis are utilised in slightly different ways through notions of rationality and net gains to mobilise and sustain the subject position of the 'flourishing hypermobile', our analysis also identified various forms of scepticism:

'More bovine droppings from 'academics' attempting to justify their existence and their large budgets of 'funding' i.e. taxpayers money being squandered on rubbish research..."

"The biggest risk of psychological and emotional damage being caused to us is by the constant stream of doom and gloom claims produced by experts and academics with far too much time on their hands and far too little of importance to do in order to be useful members of society."

"Bahahaha. Yep, our modernized, work-till-you-die cultures are far healthier that losing a little sleep here and there. I understand you are merely pointing out that there are negatives associated with long-term traveling, but it hurts to see something that can have such tremendous value put in the perspective you've put it in. I genuinely hope that people read your article, the mashable article, and the research piece and laugh out loud, as I did. Just as the glamorization hides the unseen 'costs' of travel, money hides the unseen costs of most salary positions"

Throughout all three of these extracts are explicit accounts of what has been identified as 'scientific scepticism' (e.g. Hanna, Scarles, Cohen, \& Adams, 2016) that functions through tropes of academic mistrust, miss-use of "taxpayers" money and public funds, and a general contempt towards scientific evidence. Such explicit denial of scientific evidence can be understood through what Diethelm and McKee $(2009$, p. 2) refer to as 'inversionism' in their study exploring the language through which tobacco companies attempted to actively dismiss the scientific evidence reporting the damaging health effects of smoking. In addition, reference to scientific evidence as something that is little more than laughable has also been highlighted 
in climate change talk (e.g. Gavin \& Marshall, 2011; Koteyko, Jaspal, \& Nerlich, 2013) and has been argued to be a common strategy of denial, or defence mechanism, adopted when an individual is faced with the disjuncture between their identity as an individual that participates in a particular activity, and the presentation of evidence that suggests that identity is undesirable (Cohen, 2013), in this case the identity of the frequent business traveller, and the evidence that such a lifestyle has negative impacts on that individual's physical, psychological and social health.

\subsection{The floundering hypermobile}

Whilst the position of the 'flourishing hypermobile' is clearly mobilised through notions of choice, agency and lifestyle, the binary position of the 'floundering hypermobile' functions through the direct opposite. Throughout this section we present ways in which discourses of passivity, disempowerment and distress flow throughout accounts of frequent business travel in relation to the subject position of the 'floundering hypermobile'.

\subsubsection{Disempowerment, psychological distress and loss of self}

Whilst the 'flourishing hypermobile' offered the practice of frequent flying as a mode through which the constant agentic re-creation of the self and identity could be achieved, through the subject position of the 'floundering hypermobile' we identified the direct opposite. In this position the practice of frequent flying was understood through a range of psychological and physiological tropes in which the individual is not in control and able to adopt strategies, rather they are disempowered and subject to extreme external factors, rendering them in to a position of helplessness (Seligman, 1975). As the following people comment:

"Just the thought of getting on a plane filled me with dread and anxiety"

"its cramped and tiring, crap food and a punishing work schedule in a different time zone"

"I loathe traveling these days, but still do it 4-5 months per year, a trend I'd like to see an end to in the coming years"

Negative affective and psychological effects are clearly positioned here as central elements to their experiences of frequent business travel. Agency to overcome these all-encompassing effects does not feature in these accounts. Drawing on a discourse of the body, and a psychological discourse, there are no liberating and educational travel experiences nor the position of the individual embracing the 'opportunities' of frequent travel; rather, the physical and embodied space of the plane (e.g. "cramped"), coupled with the food, and the very notion of travel appears to have profound negative psychological effects on these individuals in which "dread", "anxiety", "tiring", and "loathe[ing]" have become the core adjectives to describe their experience of frequent business travel.

Whilst the extracts above draw on physical and psychological discourses to position the floundering hypermobile as an individual that lacks agency and has external forces acting upon them, what follows are two quotes that extend this understanding through a discourse that presents both the physical and psychological impacts of frequent travel as being enduring. Such an understanding is present in contemporary medical discourses surrounding both physical and 
psychological conditions in which the individual is often only ever in remission from their conditions (Frank, 2005):

"The physical and psychological effects are long-lasting and severe. I have a travel phobia centred around a fear of airports, which I have work to overcome on every holiday. When I finished my travelling, I was overweight, drinking too much, not working productively, and disconnected from my local community, and in fact people in general. My skin was a mess, my stance was uneven due to lugging a laptop around".

"Like many frequent travellers, you get to loathe it after a while, and I have met many people who on retirement like myself go on a plane as little as possible, and some who have travel phobia."

Thus in these accounts the position of the 'floundering hypermobile' functions through a loss of agency, a sense of disempowerment, and further an understanding of the self as a fractured, fragmented individual that suffers from the enduring effects of the practice of frequent flying. However, there were some that established a more agentic position akin to that in section 3.1.1 of this analysis: their agency was not understood in a self-fulfilling manner, rather it was presented in a way in which agency was largely restricted to coping mechanisms to survive:

"You get there, power through your meeting, coax your clients into leaving early for the day, and then hit the bar SO HARD that by the time you leave in your Uber for the airport..., you're not even sure you should be allowed to board."

\subsubsection{Living the 'low' life: loss and family life}

Reflecting back to section 3.1.2 of the analysis, lifestyles and the agentic, glamorous and celebrity-like ways of being appeared central to the ways in which the 'flourishing hypermobile' established their identity in relation to their frequent business travel. Almost identical discourses surrounding glamour and celebrities were also present in the construction and maintenance of the subject position of the 'floundering hypermobile'. However, what functions to position this in direct opposition to the previous accounts is the distinct lack of agency and control, and the presentation of the self as a social being in which identities are constructed through close social groups as opposed to practices or distant social groups (e.g. seeing other cultures). As the following people highlight:

"...everyone, including my x-wife thought I was having 'the time of my life', always in first class, always upgraded, always expensive steak houses, cool cities, top tier hotels, jw's etc. reality is it sucked. I never once used the pool. Up in hotel rooms till 2 am working on the next meeting presentation, clearing emails at 1am, waking up and not always knowing what city your in, downstairs hotel lobby at 7am, etc. I had a strategy for never missing an early meeting after a late night out with the team, fall asleep fully dressed and ready to go in the hotel lobby. I never missed an early meeting. Today I have a 'lifetime' club status with the larger hotel chains and the airlines, I could write a book on the dos and don'ts tips and tricks for frequent travellers, and I generally dislike air travel. If I had to do it all over, I'd find a job/career that keeps me home. I missed too much family time, and being away was a large part of my eventual divorce." 
"I am now retired but travelled all my adult life, as a VP of sales for several international telecoms companies. I went thru several marriages, was lonely all the time. I probably should have filed for medical treatment for multiple psychological problems, but never felt safe in doing so. I never got compensated for having to live in foreign countries and giving up any normal life. I just think companies need to recognize that international travel, constantly, is not a benefit but a major hardship"

Throughout both of these accounts are many of the same associations between "first class", "top tier hotels", "lifetime club status", and the more personal social identity constructions of the educated and management level individual ("VP of sales for several international telecoms companies") similar to that of the "international educator". However, through a psychological discourse of loss, physical discourse surrounding the impact on one's body, and a social discourse concerning the family, these two extracts highlight the extent to which the 'floundering hypermobile' lacks agency and is acted upon by the practices of frequent travel. In addition, explicit acknowledgement of the 'flourishing hypermobile' and 'experienced' traveller is present, however this is done not to express agency and show how they are managing/exploiting their position, but rather to reject this position and offer up the more passive position in which agency is removed through psychological tropes of disorientation, loss of family time, eventual family breakups, and ultimate loneliness.

Such understandings of the family, as opposed to work status of 'adventure', as central yet unappreciated/unattainable aspects to the frequent business travellers' lifestyle and identities are further compounded in the expressions of loss, regret, and distress central to the following extracts:

"Timely piece as I start a 2 day trip to Singapore to deliver servers because FedEx isn't fast enough. Am I excited? Sure, I haven't been there before. However, I'm also missing a weekend with my family, flying for 28+ hours each direction, and expected to be immediately working in a data centre on arrival, at $1 \mathrm{am}$, during Singapore's $50^{\text {th }}$ anniversary holiday. Anyone who thinks this is a vacation is so, so wrong"

"Never knew of these risks as someone who travels 150 days + every year, never more than 30 days max at one place. Family life? What family? They don't consider me as one of them!"

"...there has been many time I would have killed not to have to go for lots of reason, the main one being I lost out many, many times on enjoying my young kids growing up and that time never comes back."

Thus in these accounts, it is not the identity of the successful business person that explores the world at the company's expense in a celebrity-like fashion that is the identity aligned to the subject position, rather in direct opposition to contemporary constructions of this identity project, the family here is presented as the central component to a meaningful life and demonstrates the lack of agency in obtaining this for the 'floundering hypermobile'.

\subsubsection{Net losses and the irrational thinker}

The final section of this analysis explores the ways in which the discourses surrounding the rational thinker (explored in 3.1.3) function in an entirely different way when examining them 
through the subject position of the 'floundering hypermobile'. In these accounts, agency takes centre stage for the first time in the position of the 'floundering hypermobile'. Indeed, agency here is utilised to explicitly refer to the 'other' (the flourishing hypermobile) to actively challenge their perception of the position they are faced with in order to highlight the delineating loss, suffering and pain so prominent in the accounts of the 'floundering hypermobile'.

"I still know a lot of people who take perverse pride in being stuck on airplanes for a significant proportion of their lives, just as coal miners used to feel macho about going down the pit to get pneumoconiosis. Self-deception may be vital when you have no control over your travel plans but for the rest of us avoidance is the nicest strategy of all"

"the only people who think its glamorous are the ones who haven't had to endure the slog of taxi, airport, taxi, office, hotel, office, taxi, airport, taxi, collapse exhausted from jet lag etc"

In the first of these two extracts, rational thinking is draw upon to examine the ways in which individuals that engage in frequent business travel and present it as a benefit to their lives are presented as perversions of reality. Rather than an expression of passivity, this account takes agency as its central point to explicitly challenge the "self-deception" of control of the 'flourishing hypermobile' and likens it to the negative impacts associated with coal miners and expresses the ways in which discourses of masculinity at the time were mobilised to facilitate a sense of pride and meaning in an inherently problematic form of work. In the second extract a similar strategy is adopted however here the suggestion of the 'inexperienced' traveller is presented as the source for the (irrational) assumption that frequent business travel is a "glamorous" benefit or perk of the job. Such a distancing from the notions of the benefits and glamour of frequent business travel, through the utilisation of the metaphor of the 'experienced' traveller, is further present in the following extract:

"Business travel glamorous? Maybe in the time of the Titanic. As a multi-million mile guy I can tell you that business travel is the last thing I want to do but...here we go again!"”

Indeed, such reference to a 'nostalgic' past time in which travel and business travel particularly is presented as a benefit was also presented as an irrational way of thinking. As the following person comments:

"The mystery is why business travel was ever seen as glamorous. It has been a clever trick of the industry over the last 40 to 50 years to get travel being seen as a perk of a job, instead of a huge imposition"

In a similar light to the strategies of dismissing the negative health impacts of smoking, the glamorization of business travel is viewed as a product of a clever set of marketing discourses.

\section{Conclusions}

This article sought to use discourse analysis to evaluate the ways in which people negotiate and respond to explicit physical, psychological and social health warnings surrounding 
hypermobility. This was achieved through an analysis of media comments on Cohen and Gössling's (2015) article 'A darker side of hypermobility'. The analysis has revealed that contemporary discourses surrounding frequent flying construct and locate individuals through two key subject positions. In summary, the subject position of the 'flourishing hypermobile' embraces frequent business travel as an integral part of their happiness and identity, and either denies the negative health and wellbeing implications, or presents strategies to overcome them. In contrast, the subject position of the 'floundering hypermobile' understands frequent business travel as a source of physiological and psycho-social distress, which engenders a fragmented and problematic identity. The floundering position seeks solace in the public dissemination of the health warnings surrounding hypermobility, and displays a desire to reduce travel frequency, but gives emphasis to a lack of agency to do so.

These findings consequently contribute to the emerging research problem of whether and how health and wellbeing concerns affect changes in travel. This research would suggest that such changes are unlikely: flourishing hypermobiles are unlikely to change behaviour, while floundering hypermobiles viewed reductions in business travel as beyond their perceived locus of control. As there is a notable distinction in the findings between active business travellers and those looking back at their professional lives or those unable to accommodate family life and travel, we also propose that those still in early career stages are far less likely to critically assess their lifestyles, as this would result in cognitive dissonance. In other words, it would be rational from physical, psychological and social health points of view to change travel patterns, but this interferes with perceived needs to engage with hypermobile lives. Consequently, more 'seasoned' travellers, or those looking back at their careers, appear to more often be critical of hypermobility, or even regretting their earlier lifestyles.

To address this situation, it will consequently be necessary to invest efforts at changing the cultural discourses and structures of human management resource (HRM) practices and employment regulations within organisations. This includes affecting the travel managers that large organisations often employ to implement a corporate travel management (CTM) programme and its consequent business travel routines (Aguiléra 2014; Gustafon 2012). Barish and Dilchert (2010) took a step in this direction in arguing that human resource managers must move to protect employees who fly frequently from radiation exposure; Aguiléra (2014) has also argued that such a strategic direction, led by CTM in organisations, will be necessary to safeguard the sustainability of business travel. Further efforts in this way will be an important step in facilitating transitions in the socio-technical regime (Geels, 2012) that reproduces and maintains frequent business travel as an accepted practice within organisations. Concrete measures that can be taken by organisations include, for instance, the implementation of policies and guidelines that:

- encourage the substitution of information and communication technologies for face-toface communication in cases where the communication needs do not require the richness afforded by physical presence (Aguiléra, Guillot \& Rallet 2012; Gustafson 2012);

- limit the number of times per month or annually that employees go on long-distance business travel, the distances travelled, the cumulative number of time zones crossed and/or the total number of nights required away from home;

- require that multiple trips are scheduled and bundled into one visit when the destinations are geographically proximate; 
- require a minimum rest period, such as three working days, in between long-distance trips;

- where distances are manageable, encourage alternative modes of ground transport, such as high-speed train, over flying (Aguiléra 2014);

- favour direct flights over flights with connections;

- allow for the booking of higher class of service, such as business class on flights or first class seats on trains, when travel time exceeds a duration of five hours. A higher market demand for business class air travel will however impact negatively on transport energy use and emissions: a person flying 100,000 pkm per year in business class, for instance, will generate twice the emissions of economy class (Gössling \& Cohen 2014).

Shifting these structures of provision in organisations, while taking care not to adversely affect business (Aguiléra 2014), has the potential to create co-benefits for occupational health and wellbeing and environmental sustainability, with the present paper evidencing that there is a segment of business travellers who are floundering and likely to embrace such systemic change. A fundamental barrier to such interventions, however, will be to convince companies to reposition business travel from a benefit to a burden.

Such a shift requires increasing resistance in public, popular and academic discourse against the presently dominant representation that business travel is an occupational perk. The reiterative counter-performance of frequent business travel as a burden, rather than a perk, must come through public micro-performances, which through advancing this counter-discourse, resist dominant 'ways of being' (Smith, 2001). The contestation and challenging of the frequent business traveller identity, glamorised in the masculine hegemonic discourse of the 'road warrior', must be gradually unseated through such critical reflections by business travellers and other stakeholders, but also through continuing academic and popular discourse that challenges this representation. This paper itself, and others that have reported on the negative consequences of business travel (e.g. Bergström 2010; Black \& Jamieson 2007; Cohen \& Gössling 2015; Tretyakevich 2015), as well as ongoing media coverage reporting on the negative aspects of frequent travel, such as CNN Business Traveller's recent news story, "Is business travel ruining your family life?" (Street, 2016), are examples of the manifold ways in which the complex dynamics of power/knowledge through which business travel came to be discursively represented as glamorous, can be gradually 'unfixed' (cf. Thorpe 2008). Failing this repositioning of the discourse on business travel, Black and Jamieson (2007, p. 36) provided an ominous warning: 'it will not be long before we see the first prosecutions brought against employers who cause injury and or disease to their workers for a failure to address the work/life issue' in business travel.

There is therefore a need for further research into how the structural factors influencing HRM and CTM practices can be shifted to reposition how business travel is perceived and regulated by organisations. This will require new lines of research that bring together understandings of HRM, CTM, organisational change and health and safety regulations, with interdisciplinary understandings of the health and wellbeing consequences of frequent travel. Such nexus thinking, which draws together the synergies between the health and environmental consequences of frequent business travel, and applies these towards enabling structural transitions in organisations, offers a new path forwards for mitigating the darker sides of business travel. 


\section{References}

Abdul-Mageed, M. M. (2008). Online News Sites and Journalism 2.0: Reader Comments on Al Jazeera Arabic. tripleC: Communication, Capitalism \& Critique. Open Access Journal for a Global Sustainable Information Society, 6(2), 59-76.

Aguiléra, A. (2008). Business travel and mobile workers. Transportation Research Part A. 42, $1109-1116$.

Aguiléra, A. (2014). Business travel and sustainability. In T. Gärling, D. Ettema \& M. Friman (Eds.), Handbook of Sustainble Travel, 215-227, Dordrecht: Springer.

Aguiléra, A., Guillot, C. \& Rallet, A. (2012). Mobile ICTs and physical mobility: Review and research agenda. Transportation Research Part A, 46, 664-672.

Anderson, E. (2015, 19/8/15). How business travel can make you seriously sick, The Telegraph. $\quad$ Retrieved from http://www.telegraph.co.uk/finance/newsbysector/transport/11811449/How-businesstravel-can-make-you-seriously-sick.html

AW. (2015, 17/8/15). The sad, sick life of the business traveller, The Economist. Retrieved from http://www.economist.com/blogs/gulliver/2015/08/frequent-flyers

Barish R.J. and Dilchert, S. (2010). Human resource responsibilities: Frequent flyer radiation exposure, Employee Responsibilities and Rights Journal, 22, 361-369.

Beaverstock, J.V., Derudder, B., Faulconbridge, J.R. \& Witlox, F. (2009). International business travel: Some explorations, Geografiska Annaler: Series B, Human Geography, 91(3), 193-202.

Bhavnani, K.-K., \& Phoenix, A. (1994). Shifting identities shifting racisms: a feminism \& psychology reader. London: Sage.

Bergström, G. (2010). Consequences of overnight work travel for personal social relations: Problems, promises, and further repercussions, Mobilities, 5(3), 369-386.

Bergström Casinowsky, G. (2013). Working life on the move, domestic life at standstill? Workrelated travel and responsibility for home and family, Gender, Work and Organization, 20(3), 311-326

Black, I., \& Jamieson, S. (2007). Up, up and fading away: The work and family life of executive international travellers. Policy and Practice in Health and Safety, 5(2) 63-78.

Clarke, J., \& Saraga, E. (2003). Embodying the social: Construction of difference. London: Routledge.

CNN (Producer). (2015, 02/05/16). The dark side of travel. Business Traveller. Retrieved from http://edition.cnn.com/videos/world/2015/10/15/spc-business-traveller-dark-side-oftravel-a.cnn

Cohen, S. (2013). States of denial: Knowing about atrocities and suffering. Cambridge: Polity Press.

Cohen, S. A., \& Gössling, S. (2015). A darker side of hypermobility. Environment and Planning A, 47(8), 166-1679.

Coole, D. (1993). Constructing and deconstructing liberty: A feminist and poststructuralist analysis. Political Studies, 41, 83-95.

Correa, T., Hinsley, A. W., \& De Zuniga, H. G. (2010). Who interacts on the Web?: The intersection of users' personality and social media use. Computers in Human Behavior, 26(2), 247-253.

Davies, B., \& Harré, R. (1999). Positioning and Personhood. In R. Harre \& L. Van Langenhove (Eds.), Positioning Theory. Oxford: Blackwell.

Dean, M. (1994). A social structure of many souls: Moral regulation, government, and selfformation. Canadian Journal of Sociology, 19, 145-168 
Diethelm, P., \& McKee, M. (2009). Denialism: what is it and how should scientists respond? The European Journal of Public Health, 19(1), 2-4.

Dittmar, H. (2008). Consumer Culture, Identity and Well-Being: The Search for the 'Good Life' and the 'Body Perfect'. Hove: Psychology Press.

Edwards, D. (2000). Extreme case formulations: Softeners, investment, and doing nonliteral. Research on language and social interaction, 33(4), 347-373.

Edwards, D., \& Potter, J. (1992). Discursive Psychology. London: Sage.

Erguven, M. S. (2015, Jun 2015). Flying Dutchman vs. Flying Chef: How National Cultures Shape the Brand Positioning of Flagship Carriers? The Cases of Royal Dutch Airlines and Turkish Airlines. Paper presented at the 16th International Academic Conference.

Fairclough, N. (2013). Critical discourse analysis: The critical study of language: Routledge.

Foucault, M. (Ed.). (1980). Power/Knowledge: Selected Interviews and Other Writings, 197277. Brighton: Harvester.

Foucault, M. (1989). The Birth of The Clinic: An Archaeology of Medical Perception (A. Sheridan Trans). London: Routledge.

Foucault, M. (1990a). The Will to Knowledge: The History of Sexuality, Volume 1 (R. Hurley, Trans). London: Penguin.

Foucault, M. (1990b). The Care of Self: The History of Sexuality, Volume 3. (R. Hurley, Trans). London: Penguin.

Foucault, M. (1991). Truth and Power. In P. Rabinow (Ed.), The Foucault Reader: An Introduction to Foucault's Thought. London: Penguin.

Foucault, M. (1992). The Use of Pleasure: The History of Sexuality, Volume 2. (R. Hurley, Trans). London: Penguin.

Foucault, M. (1997). Technologies of the Self. In P. Rabinow (Ed.), Michel foucault: Ethics Subjectivity and Truth. Harmondsworth: Penguin.

Foucault, M. (2002). The Archaeology of Knowledge. Abingdon: Routledge.

Frank, A. (2005). The remission society. In P. Conrad (Ed.), The Sociology of Health and Illness (pp. 163-166). New York: Worth Publishers.

Gavin, N. T., \& Marshall, T. (2011). Mediated climate change in Britain: Scepticism on the web and on television around Copenhagen. Global Environmental Change, 21(3), $1035-1044$.

Geels, F.W. (2012). A socio-technical analysis of low-carbon transitions: introducing the multi-level perspective into transport studies. Journal of Transport Geography, 24, 471-482.

Giddens, A. (1991). Modernity and Self-Identity: self and society in the late modern age. Stanford: Stanford University Press.

Gill, R. (2000). Discourse Analysis. In M. W. Bauer \& G. Gaskell (Eds.), Qualitative researching with image, sound and text. London: Sage.

Gössling, S. \& Cohen, S. (2014). Why sustainable transport policies will fail: EU climate policy in the light of transport taboos

Goldstein, D. (2003). Reproductive Technologies of the Self: Michel Foucault and MetaNarrative-Ethics. Journal of Medical Humanities, 24, 229-240.

Gustafson, P. (2006). Work-related travel, gender and family obligations. Work, employment and society, 20(3), 513-530.

Gustafson, P. (2012). Managing business travel: Developments and dilemmas in corporate travel management. Tourism Management, 33, 276-284.

Gustafson, P. (2014). Business travel from the traveller's perspective: Stress, stimulation and normalization, Mobilities, 9(1), 63-83. 
Hanna, P. (2013). A break from 'reality': An investigation into the 'experiments with subjectivity' on offer within the promotion of sustainable tourism in the UK. Journal of Consumer Culture, 13(3), 366-386.

Hanna, P., Scarles, C., Cohen, S., \& Adams, M. (2016). Everyday climate discourses and sustainable tourism. Journal of Sustainable Tourism, Online First. doi: 10.1080/09669582.2015.1136636

Ivancevich, J.M., Konopaske, R., \& DeFrank, R.S. (2003). Business travel stress: A model, propositions and managerial implications, Work \& Stress: An International Journal of Work, Health \& Organisations, 17(2) 138-157.

Hermans, H. (1999). The polyphony of the mind: A multi-voiced and dialogical self. In J. Rowan \& M. Cooper (Eds.), The plural self: Multiplicity in everyday life (pp. 107131). London: Sage.

Heyes, C. (2006). Foucault Goes to Weight Watchers. Hypatia, 21, 126-149.

Heyes, C. (2007). Self-Transformations: Foucault, Ethics, and Normalized Bodies. Oxford: Oxford University Press.

Kabbani, R. (1986). Europe's Myths of Orient London: Pandora Press.

Kaplan, A. M., \& Haenlein, M. (2010). Users of the world, unite! The challenges and opportunities of Social Media. Business horizons, 53(1), 59-68.

Koteyko, N., Jaspal, R., \& Nerlich, B. (2013). Climate change and 'climategate' in online reader comments: a mixed methods study. The Geographical Journal, 179(1), 74-86.

Kurz, T., Augoustinos, M. and Crabb, S., 2010. Contesting the 'national interest' and maintaining 'our lifestyle':A discursive analysis of political rhetoric around climate change. British Journal of Social Psychology, 49 (3), pp. 601-625.

Lindenberg, S., Joly, J., \& Stapel, D. (2011). The Norm-Activating Power of Celebrity The Dynamics of Success and Influence. Social Psychology Quarterly, 74(1), 98-120.

Madill, A., \& Gough, B. (2008). Qualitative Research and Its Place in Psychological Science. Psychological Methods, 13, 254-271.

Markula, P. (2003). The technologies of the self: sport, feminism, and Foucault. Sociology of Sport Journal, 20, 87-107

Marx, K., \& McLellan, D. (2000). Karl Marx: selected writings: OUP UK.

McCarthy, T. (1990). The Critique of Impure Reason: Foucault and the Frankfurt School. Political Theory, 18, 437-469.

McCracken, G. (1989). Who is the celebrity endorser? Cultural foundations of the endorsement process. Journal of consumer research, 16(3), 310-321.

McNay, L. (1994). Foucault: A Critical Introduction. Cambridge: Polity Press.

Miniwatts-Marketing-Group. (2016). The Internet Big Picture: World Internet Users and 2015 Population Stats. Retrieved 09/02/16, from http://www.internetworldstats.com/stats.htm

Oberhuber, F., \& Krzyzanowski, M. (2008). Discourse Analysis and Ethnography. In R. Wodak \& M. Krzyzanowski (Eds.), Qualitative Discourse Analysis in the Social Sciences. Basingstoke: Palgrave Macmillan.

Parker, I. (1992). Discourse dynamics: Critical analysis for social and individual psychology. London: Routledge.

Parker, I. (1994). Reflexive research and the grounding of analysis: Social psychology and the psy-complex. Journal of Community and Applied Social Psychology, 4, 239-252.

Parker, I. (1999). Critical Textwork: an introduction to varieties of discourse and analysis. Buckingham Open University Press.

Parker, I. (2004). Discursive Practice: analysis, context and action in critical research. International Journal of Critical Psychology - Psycho-social Research., 10, 150-173.

Pettigrew, T. F. (1998). Intergroup contact theory. Annual review of psychology, 49(1), 65-85. 
Potter, J., \& Wetherell, M. (1987). Discourse and Social Psychology: Beyond attitudes and behaviour. London: Sage.

Potthast, M., Stein, B., Loose, F., \& Becker, S. (2012). Information retrieval in the commentsphere. ACM Transactions on Intelligent Systems and Technology (TIST), 3(4), 68.

Riva, G., \& Galimberti, C. (2001). Towards Cyberpsychology: Mind, cognition, and society in the internet age (Vol. 2). Amsterdam: IOS Press.

Rose, N. (1989). Governing the Soul. London: Routledge.

Rose, N. (1998). Inventing Our Selves: Psychology, Power, and Personhood. Cambridge Cambridge University Press.

Shaw, S., \& Thomas, C. (2006). Social and cultural dimensions of air travel demand: Hypermobility in the UK? Journal of Sustainable Tourism, 14(2), 209-215.

Schuth, A., Marx, M., \& de Rijke, M. (2007). Extracting the discussion structure in comments on news-articles. Paper presented at the Proceedings of the 9th annual ACM international workshop on Web information and data management.

Seligman, M. E. (1975). Helplessness: On depression, development, and death: WH Freeman/Times Books/Henry Holt \& Co.

Shepherd, R. (2003). Fieldwork without remorse: Travel desires in a tourist world. Consumption, Markets and Culture, 6, 133-144.

Simons, J. (1995). Foucault and the political. London: Routledge.

Smith, M. (2001). The Face of Nature: Environmental Ethics and the Boundaries of Contemporary Social Theory. Current Sociology, 49, 49-65.

Speer, S. A., \& Potter, J. (2000). The management of heterosexist talk: Conversational resources and prejudiced claims. Discourse \& Society, 11(4), 543-572.

Stone, M.J., \& Petrick, J.F. (2013). The educational benefits of travel experiences: A literature review. Journal of Travel Research, 52(6), 731-744.

Street, F. (2016, 7/12/16). Is business travel ruining your family life? CNN Business Traveller. Retrieved from http://edition.cnn.com/2016/12/06/travel/travel-maintainingrelationships/

Striker, J., Dimberg, L. \& Liese, B.H. (2000). Stress and business travel: Individual, managerial and corporate concerns, Journal of Organizational Excellence, Winter, 3-9.

Taylor, C. (1984). Foucault on freedom and truth. Political Theory, 12, 152-183.

Thompson, C., \& Hirschman, E. (1995). Understanding the Socialized Body: A Poststructuralist Analysis of Consumers' Self-Conceptions, Body Images, and SelfCare Practices. Journal of Consumer Research, 22, 139-153.

Thorpe, H. (2008). Foucault, technologies of self, and the media: Discourses of femininity in snowboarding culture. Journal of Sport \& Social Issues, 32(2), 199-229.

Thurlow C, \& Jaworski A. (2006). The alchemy of the upwardly mobile: Symbolic capital and the stylization of elites in frequent-flyer programmes. Discourse \& Society, 17, 99-135.

Tretyakevich, N. (2015). Corporate Mobility: Impacts on Life Domains and Implications for Work-Life Balance of International Business Travelers and Expatriates. Unpublished $\mathrm{PhD}$ thesis. Università della Svizzera italiana. Available at: http://doc.rero.ch/record/258286/files/2016ECO001.pdf

Van Dijck, J. (2009). Users like you? Theorizing agency in user-generated content. Media, culture, and society, 31(1), 41.

Var, T., Brayley, R., \& Korsay, M. (1989). Tourism and world peace: Case of Turkey. Annals of Tourism Research, 16(2), 282-286.

Wang, S. W., Close, A., \& Ngamsiriudom, W. (2016). Celebrity Endorsement in the Airline Sector Celebrating America's Pastimes: Baseball, Hot Dogs, Apple Pie and Marketing? (pp. 685-689): Springer. 
Waterhouse, J., Reilly, T. \&Edwards, B. (2004). The stress of travel, Journal of Sport Sciences, 22, 946-966.

Welch, D.E., Welch, L.S. \& Worm, V. (2007). The international business traveller: A neglected but strategic human resource. International Journal of Human Resource Management, 18(2), 173-183.

Wetherell, M. (1998). Positioning and interpretative repertoires: Conversation analysis and post-structuralism in dialogue. Discourse \& Society, 9, 387-413.

Willig, C. (2008). Discourse Analysis. In J. Smith (Ed.), Qualitative Psychology: A practicle guide to research methods (2nd ed.). London: Sage.

Yates, S., \& Hiles, D. (2010). Towards a 'Critical Ontology of Ourselves'?: Foucault, Subjectivity and Discourse Analysis. Theory \& Psychology, 20, 52-75. 